Brazilian Journal

of Chemical

ISSN 0104-6632

Engineering

\title{
EVALUATION OF OPERATIONAL PARAMETERS ON THE PRECIPITATION OF ENDOGLUCANASE AND XYLANASE PRODUCED BY SOLID STATE FERMENTATION OF Aspergillus niger
}

\author{
C. S. Farinas ${ }^{1 *}$, L. M. Scarpelini ${ }^{1}$, E. A. Miranda ${ }^{2}$ and V. Bertucci Neto ${ }^{1}$ \\ ${ }^{1}$ Embrapa Instrumentação Agropecuária, Phone: + (55) (16) 21072908, Fax: + (55) (16) 2107-2902, \\ Rua XV de Novembro 1452, CEP: 13560-970, São Carlos - SP, Brazil. \\ E-mail: cristiane@cnpdia.embrapa.br \\ ${ }^{2}$ LEBp, Laboratório de Engenharia de Bioprocessos, Departamento de Processos Biotecnológicos, \\ FEQ, UNICAMP, 13083-970 Campinas - SP, Brazil.
}

(Submitted: April 7, 2010 ; Revised: August 5, 2010 ; Accepted: September 27, 2010)

\begin{abstract}
In order to develop cost effective processes for converting biomass into biofuels, it is essential to improve enzyme production yields, stability and specific activity. In this context, the aim of this work was to evaluate the concentration of two enzymes involved in the hydrolysis of biomass, endoglucanase and xylanase, through precipitation. Statistical experimental design was used to evaluate the influence of precipitant agent concentration (ammonium sulfate and ethanol), aging time, and temperature on enzyme activity recovery. Precipitant agent concentration and aging time showed a statistically significant effect at the $95 \%$ confidence level, on both enzyme activity recoveries. The recovery of endoglucanase with ammonium sulfate and ethanol reached values up to 65 and $61 \%$, respectively. For xylanase, the recovery rates were lower, 27 and 25\% with ammonium sulfate and ethanol, respectively. The results obtained allowed the selection of the variables relevant to improving enzyme activity recovery within operational conditions suitable for industrial applications.

Keywords: Endoglucanase; Xylanase, Cellulases; Precipitation; Downstream processing; Solid-state fermentation.
\end{abstract}

\section{INTRODUCTION}

Cellulose is the most abundant natural renewable resource of the planet (Zhang et al., 2006) and energy production from lignocellulosic biomass is an important alternative route that has been studied and debated worldwide. Although there are available technologies for converting cellulose into biofuels, most of them are hindered by technical or economic difficulties. The enzymatic conversion of lignocellulosic biomass to obtain fermentable sugars has been identified as a route of great industrial interest to increase ethanol productivity in a sustainable manner (Ogier et al. 1999; Wyman, 1999; Knauf and
Moniruzzaman, 2004). However, the enzymatic hydrolysis of cellulose using cellulases, although an alternative of lower environmental impact, still requires the development of technologies that can reduce the costs of these enzymes.

Cellulases are a complex of enzymes that act synergistically to degrade insoluble cellulose into soluble fermentable sugars. The classification of cellulases according to their action on the cellulosic substrate is divided into three main classes: endoglucanase (endo-1,4- $\beta$-D-glucanase, EC 3.2.1.4), which acts randomly on soluble and insoluble cellulose chains; exoglucanases (1,4- $\beta$-D-glucancellobiohydrolase, EC 3.2.1.91), which acts to

*To whom correspondence should be addressed 
preferentially liberate cellobiose from the ends of the cellulose chain; and $\beta$-glycosidases ( $\beta$-D-glucoside glucanohydrolase, cellobiase, EC 3.2.1.21) that hydrolyze cellobiose dimers to glucose (Himmel et al., 1999). A typical composition of lignocellulosic materials (as dry mass) is 35 to $50 \%$ cellulose, 20 to $35 \%$ hemicellulose and 5 to 30\% lignin (Lynd et al., 1999). The presence of xylanase in the enzymatic cocktail is of great importance to break down hemicellulose in the plant cell wall, since this group of branched polysaccharides connects strongly with each other and the surface of cellulose microfibrils, forming crosslinks via hydrogen bonds that hinders the action of cellulases. Xylanases are responsible for xylan hydrolysis, which is the main polysaccharide component of hemicelluloses in hard wood and grasses. Cellulases and xylanases are also industrially important enzymes in the textile, pulp and paper and food industries. Compared to other industrial enzymes, cellulases are in third position worldwide in terms of dollar volume (Wilson, 2008). However, this position will certainly ascend with the use of cellulases in the process of converting biomass into biofuels.

Existing technologies for microbial enzyme production are conducted either in the liquid phase, known as submerged fermentation $(\mathrm{SmF})$, or using solid substrates, the so called solid-state fermentation (SSF). SSF is defined as the growth of microorganisms on a moist solid substrate in the absence of free water (Chahal, 1985). Growth of filamentous fungi in SSF bioreactors is considered to be advantageous since the solid medium simulates its natural habitat. This benefit is extended to the production of enzymes, providing greater productivity when compared to the process of submerged fermentation. Moreover, the enzymes produced by SSF are more concentrated and downstream processing (DSP) costs are minimized.

The choice of the DSP unit operations is a major challenge in defining a biotechnological process, because the bioproduct loss in the multiple operations of separation, concentration and purification may compromise the efficiency of the whole process. Besides, for the case of industrial enzymes, cost reduction is a priority. In this sense, the technique of precipitation can be very effective in providing the necessary concentration of the enzyme extract, since high purity, obtained usually by chromatographic processes, may not be required.

Several studies focusing on the isolation and purification of cellulases and xylanases have been made due to the great interest in understanding the action of these biomass degrading enzymes. However, most of them describe the precipitation step at a single specific condition (Bokhari et al., 2009; Li et al., 2009; Jabbar et al., 2008; Ninawa et al., 2008; Saha, 2004; Oikawa et al., 1997). Finding the optimum operational condition for precipitation can involve a study of different variables such as the type and concentration of the precipitant agent, temperature, aging time, agitation, $\mathrm{pH}$ and so forth. The conventional method for the optimization of a system with many variables usually evaluates one factor at a time. However, this type of method can be very time-consuming and also does not reveal the synergistic effects between the variables. The use of statistical experimental design followed by response surface methodology (RSM) to identify the optimum conditions for precipitation of proteins can be very effective for analyzing the relationships among a number of parameters that affect the overall process.

In this context, the aim of this work was to evaluate the technique of precipitation for the concentration of enzymes produced by a selected strain of the filamentous fungi Aspergillus niger cultivated in solidstate fermentation (SSF). Statistical experimental design with analysis of the response surface was used to study the influence of the concentration of two precipitation agents (ammonium sulfate and ethanol), aging time, and temperature on endoglucanase and xylanase activity recovery.

\section{METHODOLOGY}

\section{Microorganism}

The microorganism used in this study was a wild type strain of $A$. niger from the Embrapa Food Technology collection (Rio de Janeiro, Brazil) that was isolated from black pepper (Couri and Farias, 1995). The culture was kept on dry sand under freezing conditions $\left(-18^{\circ} \mathrm{C}\right)$. Microorganism activation was carried out in basic medium agar slants incubated for 7 days at $32^{\circ} \mathrm{C}$ (Couri and Farias, 1995). After this period, conidia were harvested by adding $10 \mathrm{~mL}$ of $0.1 \%$ Tween- 80 to the slant.

\section{Inoculum Preparation}

A volume of $1 \mathrm{~mL}$ of the spore suspension was inoculated into a $250 \mathrm{~mL}$ Erlenmeyer flask containing ground corn cob and a nutrient medium, according to Couri and Farias (1995). The inoculum was incubated for 5 days at $32^{\circ} \mathrm{C}$. The spore concentration in the suspension was determined by counting the spores in a Neubauer chamber. The inoculum volume used to inoculate the fermentation 
medium was calculated to obtain a final concentration of $10^{7}$ spores per gram of solid medium.

\section{Fermentation Conditions}

Fermentations were carried out in $500 \mathrm{~mL}$ Erlenmeyer flasks using wheat bran with a moisture level of $60 \%$ (adjusted with $0.9 \%$ (w:v) ammonium sulfate solution in $0.1 \mathrm{~mol} / \mathrm{L} \mathrm{HCl}$ ) as solid substrate. Fermentation was carried out at $32^{\circ} \mathrm{C}$ for $72 \mathrm{~h}$. After this period, the enzymes were extracted by adding $0.2 \mathrm{~mol} / \mathrm{L}$ sodium acetate buffer at $\mathrm{pH} 4.5$ into each flask. The suspension was stirred at $120 \mathrm{rpm}$ for $1 \mathrm{~h}$ at $32^{\circ} \mathrm{C}$ and the enzymatic solution was recovered by filtration. The recovered enzyme extracts were stored at $-18^{\circ} \mathrm{C}$ for further analysis.

\section{Precipitation Conditions}

The experimental procedure of precipitation consisted of adding drop-wise a volume of a saturated solution of ammonium sulfate or ethanol to the crude enzyme extract under agitation. The precipitation was carried out in $2 \mathrm{~mL}$ tubes inside a controlled temperature bath. The volume of the precipitant agent added, as well as the temperature and aging time varied according to the experimental design. The precipitate formed was collected by centrifugation at $3000 \mathrm{~g}$ for $15 \mathrm{~min}$ and dissolved in $0.2 \mathrm{~mol} / \mathrm{L}$ sodium acetate buffer at $\mathrm{pH} 4.5$ for enzyme activity quantification.

\section{Experimental Design}

A complete factorial design followed by response surface analysis was used to evaluate the effect of concentration of the precipitant agent (ammonium sulfate and ethanol), temperature and aging time on the efficiency of endoglucanase and xylanase precipitation by measuring the enzyme activity recovered. The experimental design selected was a $2^{3}$ complete factorial design comprising of eleven runs, corresponding to eight factorial points and three central points, with the experiments carried out in a random order. The independent variable values and their coded levels are given in Table 1. Response variables were endoglucanase and xylanase activity recoveries. Statistica software (Statsoft, version 7.0) was used for the analysis of the experimental data, the generation of the ANOVA (analysis of variance) data, and the plotting of response surfaces. A firstorder polynomial model of the form of Equation (1) was used to fit the data:

$$
\begin{aligned}
Y= & \beta_{0}+\beta_{1} X_{1}+\beta_{2} X_{2}+\beta_{3} X_{3}+ \\
& \beta_{12} X_{1} X_{2}+\beta_{13} X_{1} X_{3}+\beta_{23} X_{2} X_{3}
\end{aligned}
$$

where $\mathrm{Y}$ is the predicted response for endoglucanase or xylanase activity recovery; $\beta_{0}$ is the intercept term; $\beta_{1}, \beta_{2}$ and $\beta_{3}$ are the linear coefficients; $\beta_{12}, \beta_{13}$ and $\beta_{23}$ are the interaction coefficients; and $\mathrm{X}_{1}, \mathrm{X}_{2}$ and $\mathrm{X}_{3}$ are the coded independent variables: concentration of precipitant agent (ammonium sulfate or ethanol), temperature and aging time, respectively. The terms which were not statistically significant were removed from the model and added to the lack of fit.

Table 1: Independent variables and their coded levels for the complete $2^{3}$ factorial design of endoglucanase and xylanase activity recovery after precipitation.

\begin{tabular}{|l|c|r|r|}
\hline \multirow{2}{*}{ Independent variable } & \multicolumn{3}{|c|}{ Coded Level } \\
\cline { 2 - 4 } & $\mathbf{- 1}$ & $\mathbf{0}$ & $\boldsymbol{+ 1}$ \\
\hline Final concentration of & 40 & 60 & 80 \\
precipitant* $(\%)$ & 10 & 20 & 30 \\
Temperature $\left({ }^{\circ} \mathrm{C}\right)$ & 60 & 120 & 180 \\
Time (min) & \\
\hline
\end{tabular}

*Ammonium sulfate saturation or ethanol (v/v).

\section{Enzyme Activities}

Endoglucanase activity was measured by using an assay based on Ghose methodology (Ghose, 1987). Briefly, a volume of the appropriately diluted enzyme extract was incubated at $50^{\circ} \mathrm{C}$ for $10 \mathrm{~min}$ with a $1 \%$ CMC (Sigma, USA) solution prepared in $50 \mathrm{mM}$ citrate buffer at $\mathrm{pH} 4.8$ as substrate. One unit of endoglucanase activity corresponds to $1 \mu \mathrm{mol}$ of glucose released per minute at $\mathrm{pH} 4.8$ and $50^{\circ} \mathrm{C}$. Xylanase activity was measured accordingly to Bailey (1992), by incubating a volume of the appropriately diluted enzyme extract at $50^{\circ} \mathrm{C}$ for $30 \mathrm{~min}$ with a $1 \%$ oat spelt xylan (Sigma, USA) solution prepared in 100 $\mathrm{mM}$ sodium acetate buffer, $\mathrm{pH} 5.0$, as substrate. One unit of xylanase activity corresponds to $1 \mu \mathrm{mol}$ of xylose released per minute at $\mathrm{pH} 5.0$ and $50^{\circ} \mathrm{C}$. The quantification of the reducing groups released from both assays was done according to the DNS method developed by Miller (1959).

\section{RESULTS AND DISCUSSIONS}

The effects of temperature, aging time and concentration of the precipitating agent on the efficiency of endoglucanase and xylanase precipitation from a crude enzyme extract were 
evaluated using a $2^{3}$ complete factorial design. Table 2 presents the experimental conditions and the results for endoglucanase and xylanase activity recoveries with ammonium sulfate and ethanol.

\section{Precipitation with Ammonium Sulfate}

Precipitation of endoglucanase and xylanase from a crude SSF enzyme extract was first evaluated by using ammonium sulfate as the precipitant agent at concentrations varying from 40 to $80 \%$ saturation. However, no precipitation was detected in runs 1,3 and 5 (all of them using 40\% saturation). The higher efficiency of precipitation for both endoglucanase and xylanase activities was achieved at $80 \%$ ammonium sulfate saturation, $10^{\circ} \mathrm{C}$ and an aging time of $180 \mathrm{~min}$, resulting in activity recoveries of $56 \%$ and $27 \%$, respectively.
The percent saturation and aging time as well as the term related to their interaction showed statistical significance, within a confidence limit of $95 \%$, for endoglucanase and xylanase activity recoveries, all of them being positive effects (Table 3 ). The positive effect of the factors means that an increase in one of them will favor activity recovery, while the interaction means that these effects cannot be interpreted separately, i.e., the effect of these factors cannot be explained by the sum of their individual effects. Analyzing the effect of each independent variable on the response variables, the concentration of the precipitant ammonium sulfate was the one that had a greater effect on both endoglucanase and xylanase recovery, followed by the aging time. Therefore, an increase in any of these two variables (within the range tested) would lead to higher values of enzyme recovery.

Table 2: Endoglucanase and xylanase activity recovery after precipitation using ammonium sulfate and ethanol under different conditions.

\begin{tabular}{|c|c|c|c|c|c|c|c|}
\hline \multirow[b]{2}{*}{ Run } & \multicolumn{3}{|c|}{ Coded levels } & \multicolumn{2}{|c|}{$\begin{array}{c}\text { Ammonium Sulfate } \\
\text { Activity Recovery (\%) }\end{array}$} & \multicolumn{2}{|c|}{$\begin{array}{c}\text { Ethanol } \\
\text { Activity Recovery }(\%)\end{array}$} \\
\hline & \begin{tabular}{|c|} 
Final \\
concentration of \\
precipitant $*(\%)$
\end{tabular} & $\begin{array}{c}\text { Temperature } \\
\left({ }^{\circ} \mathrm{C}\right)\end{array}$ & Time (min) & Endoglucanase & Xylanase & Endoglucanase & Xylanase \\
\hline 1 & -1 & -1 & -1 & 0 & 0 & 6 & 3 \\
\hline 2 & 1 & -1 & -1 & 23 & 8 & 20 & 8 \\
\hline 3 & -1 & 1 & -1 & 0 & 0 & 10 & 7 \\
\hline 4 & 1 & 1 & -1 & 35 & 16 & 31 & 20 \\
\hline 5 & -1 & -1 & 1 & 0 & 0 & 14 & 8 \\
\hline 6 & 1 & -1 & 1 & 56 & 27 & 40 & 23 \\
\hline 7 & -1 & 1 & 1 & 3 & 2 & 12 & 5 \\
\hline 8 & 1 & 1 & 1 & 47 & 17 & 21 & 18 \\
\hline 9 & 0 & 0 & 0 & 10 & 9 & 22 & 10 \\
\hline 10 & 0 & 0 & 0 & 13 & 8 & 19 & 8 \\
\hline 11 & 0 & 0 & 0 & 11 & 7 & 21 & 8 \\
\hline
\end{tabular}

*ammonium sulfate saturation or ethanol (v/v).

Table 3: Statistical analysis for endoglucanase and xylanase activity recovery using ammonium sulfate as precipitant agent.

\begin{tabular}{|l|c|c|c|c|c|c|c|c|}
\hline & \multicolumn{9}{|c|}{ Ammonium Sulfate } \\
\cline { 2 - 9 } & \multicolumn{4}{|c|}{ Endoglucanase } & \multicolumn{3}{c|}{ xylanase } \\
\hline \multirow{2}{*}{ Factor } & Effect & $\begin{array}{c}\text { Standard } \\
\text { Error }\end{array}$ & $\mathbf{t}(\mathbf{2})$ & $\mathbf{p}$ & Effect & $\begin{array}{c}\text { Standard } \\
\text { Error }\end{array}$ & $\mathbf{t}(2)$ & $\mathbf{p}$ \\
\hline mean & $20.50^{*}$ & 0.54 & 37.96 & 0.00 & $8.75^{*}$ & 0.35 & 24.75 & 0.00 \\
curvature & $-18.33^{*}$ & 2.07 & -8.86 & 0.01 & -1.50 & 1.35 & -1.11 & 0.38 \\
Final concentration & $39.50^{*}$ & 1.08 & 36.57 & 0.00 & $16.50^{*}$ & 0.71 & 23.33 & 0.00 \\
of precipitant (1) & 1.50 & 1.08 & 1.39 & 0.30 & 0.00 & 0.71 & 0.00 & 1.00 \\
Temperature (2) & $12.00^{*}$ & 1.08 & 11.11 & 0.01 & $5.50^{*}$ & 0.71 & 7.78 & 0.02 \\
Time(3) & 0.00 & 1.08 & 0.00 & 1.00 & -1.00 & 0.71 & -1.41 & 0.29 \\
1x2 & $10.50^{*}$ & 1.08 & 9.72 & 0.01 & $4.50^{*}$ & 0.71 & 6.36 & 0.02 \\
1x3 & -4.50 & 1.08 & -4.17 & 0.05 & $-4.00^{*}$ & 0.71 & -5.66 & 0.03 \\
2x3 & & & & & & & &
\end{tabular}

*Significant at the 0.05 level. 
The ANOVA analysis for both endoglucanase and xylanase activity recoveries (Table 4) showed that the coefficient of correlation (0.9691 and 0.9260 , respectively) and the F test (16.81 and 4.16 times higher than the tabulated F-value at the $95 \%$ level of confidence, respectively), obtained when the analysis was carried out after exclusion of the terms that were not statistically significant, were satisfactory for the prediction of the models of Equations (2) and (3):

Endoglucanase Activity Recovery (\%) =

$20.5019 .75 \mathrm{X}_{1}+6.00 \mathrm{X}_{3}+5.25 \mathrm{X}_{1} \mathrm{X}_{3}$

Xylanase Activity Recovery (\%) =

$8.75+8.25 \mathrm{X}_{1}+2.75 \mathrm{X}_{3}+2.25 \mathrm{X}_{1} \mathrm{X}_{3}-2.00 \mathrm{X}_{2} \mathrm{X}_{3}$

where $X_{1}, X_{2}$ and $X_{3}$ are the coded variables concentration of precipitant agent (ammonium sulfate), temperature and aging time, respectively. Even though the curvature was statistically significant for endoglucanase recovery (Table 4), the coefficient of correlation (0.9691), the F-test (16.81 times higher than the tabulated F-value) and the lack of fit showed the adequacy of the linear model. As for xylanase recovery, the curvature and the lack of fit were not statistically significant, i.e., in the region investigated the data could be fit well by the linear model. The models of Equations (1) and (2) were used to describe the response surface plots for precipitation using ammonium sulfate (Figures 1 and 2 ). The increase in saturation and time favored the precipitation of both enzymes.

The effect of salt concentration on the results can be explained by the salting out effect. The addition of salt in high concentration reduces the electrostatic repulsion between like-charged groups at the protein surface and disturbs the structure of water molecules around the protein, making the aqueous salt solution a poor solvent for proteins, which precipitate out (Kumar et al., 2003). Salting out is also largely dependent on the hydrophobicity of the protein, since high salt concentration promotes the aggregation of hydrophobic patches on the protein surface (Scopes, 1994). The positive effect of aging time on enzyme recovery can be explained by the fact that a longer aging time increases the probability of nuclei formation due to collision among the molecules. Once the nuclei reach a critical size, they continue to grow.

Although the temperature was not statistically significant for the efficiency of both endoglucanase and xylanase precipitation, it showed a positive effect. According to Scopes (1994), temperature affects the solubility of proteins at high salt concentrations in an unusual way because of its effect on the hydrophobic interaction and, in the salting out range, the solubility of proteins generally decreases with increasing temperature. This phenomenon was also observed here, corroborating that hydrophobic interactions play a role in precipitation.

Table 4: Analysis of variance (ANOVA) for endoglucanase and xylanase activity recovery using ammonium sulfate as precipitant agent.

\begin{tabular}{|c|c|c|c|c|c|c|c|c|c|c|}
\hline \multirow[b]{3}{*}{ Factor } & \multicolumn{10}{|c|}{ Ammonium Sulfate } \\
\hline & \multicolumn{5}{|c|}{ Endoglucanase } & \multicolumn{5}{|c|}{ xylanase } \\
\hline & SS & df & MS & $\mathbf{F}$ & $\mathbf{P}$ & SS & df & MS & $\mathbf{F}$ & $\mathbf{p}$ \\
\hline Curvature & $183.33^{*}$ & 1 & 183.33 & 78.57 & 0.01 & 1.23 & 1 & 1.23 & 1.23 & 0.38 \\
\hline $\begin{array}{l}\text { Final concentration } \\
\text { of precipitant (1) }\end{array}$ & $3120.50 *$ & 1 & 3120.50 & 1337.36 & 0.00 & $544.50 *$ & 1 & 544.50 & 544.50 & 0.00 \\
\hline Temperature (2) & 4.50 & 1 & 4.50 & 1.93 & 0.30 & 0.00 & 1 & 0.00 & 0.00 & 1.00 \\
\hline Time(3) & $288.00^{*}$ & 1 & 288.00 & 123.43 & 0.01 & $60.50^{*}$ & 1 & 60.50 & 60.50 & 0.02 \\
\hline $1 \times 2$ & 0.00 & 1 & 0.00 & 0.00 & 1.00 & 2.00 & 1 & 2.00 & 2.00 & 0.29 \\
\hline $1 \times 3$ & $220.50 *$ & 1 & 220.50 & 94.50 & 0.01 & $40.50 *$ & 1 & 40.50 & 40.50 & 0.02 \\
\hline $2 \times 3$ & 40.50 & 1 & 40.50 & 17.36 & 0.05 & $32.00 *$ & 1 & 32.00 & 32.00 & 0.03 \\
\hline${ }^{1}$ Lack of Fit & 117.00 & 4 & 29.25 & 12.54 & 0.08 & 52.00 & 3 & 17.33 & 17.33 & 0.06 \\
\hline Pure Error & 4.67 & 2 & 2.33 & & & 2.00 & 2 & 1.00 & & \\
\hline Total SS & 3934.00 & 10 & & & & 732.73 & 10 & & & \\
\hline F cal & 73.11 & & & & & 18.85 & & & & \\
\hline Ftab & 4.35 & & & & & 4.53 & & & & \\
\hline Fcal/Ftab & 16.81 & & & & & 4.16 & & & & \\
\hline $\mathrm{R}^{2}$ & 0.9691 & & & & & 0.9260 & & & & \\
\hline
\end{tabular}

*Significant at the 0.05 level.

1. Values described for lack of fit and below were obtained for ANOVA analysis after exclusion of non-significant factors.

$\mathrm{SS}=$ sum of squares; $\mathrm{df}=$ degrees of freedom; $\mathrm{MS}=$ mean square; $\mathrm{R}^{2}=$ Coefficient of correlation. 


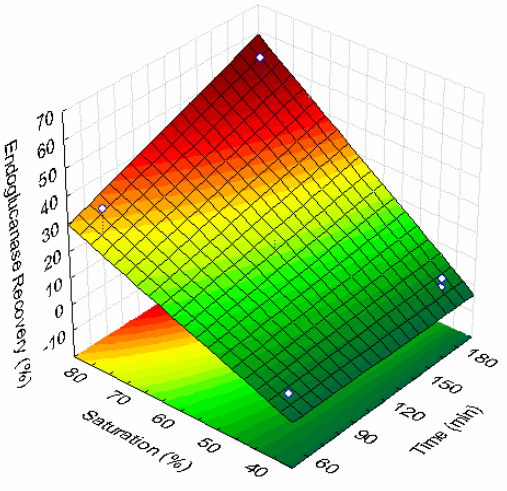

Figure 1: Response surface plot for the effect of aging time and percent saturation on endoglucanase activity recovery after precipitation with ammonium sulfate.

Even though the salt concentration range required for precipitation is not an absolute property of the protein - since it is dependent on both the properties of the other proteins present and the protein concentration in the starting solution (Scopes, 1994) the results presented here for endoglucanase precipitation using ammonium sulfate at the lower level $(40 \%)$ were also observed by Oikawa et al. (1997). These authors studied the purification and characterization of an endoglucanase from Acetobacter xylinum using precipitation as the first step of purification and found that the enzyme was hardly precipitated at all from the culture broth by addition of ammonium sulfate at final concentrations of $40 \%$ and $60 \%$ saturation.

However, other studies using endoglucanase precipitation with ammonium sulfate as the initial purification step report recoveries varying from 60 to $86 \%$. Li et al. (2009) described the purification of a novel endoglucanase from the gastric juice of the mollusc Ampullaria crossean. A recovery of $61.9 \%$ was achieved when the enzyme extract was added to $55 \%$ saturation of ammonium sulfate and left overnight at $4^{\circ} \mathrm{C}$. Jabbar et al. (2008) used precipitation as part of the purification of a novel endoglucanase from Gymnoascella citrina produced under solid-state conditions. Solid ammonium sulfate was added to the crude enzyme until $35 \%$ saturation at $0^{\circ} \mathrm{C}$ and left overnight at $4^{\circ} \mathrm{C}$. After centrifugation, the pellet was discarded and more solid ammonium sulfate was added to the supernatant to attain a $65 \%$ saturation (again at $0^{\circ} \mathrm{C}$ and kept overnight at $4^{\circ} \mathrm{C}$ ), resulting in a recovery of $86 \%$.

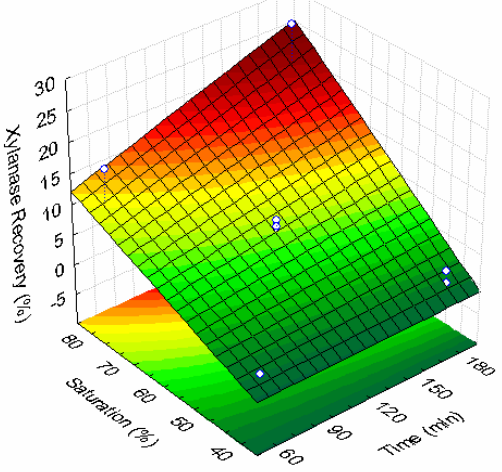

Figure 2: Response surface plot for the effect of aging time and percent saturation on xylanase activity recovery after precipitation with ammonium sulfate.

Xylanase precipitation with ammonium sulfate as an initial purification step was also described in the literature with recoveries varying from 59 to $72 \%$ : Bokhari et al. (2009) purified xylanases produced from a strain of Thermomyces lanuginosus and its mutant by using a sequence of two steps: an overnight ammonium sulfate precipitation with 30$40 \%$ saturation at $0^{\circ} \mathrm{C}$ (which resulted in recovery yields of 69.80 and $71.64 \%$ ) and gel filtration chromatography. Purification of xylanases from Streptomyces cyaneus using precipitation up to $60 \%$ saturated ammonium sulfate left overnight at $4^{\circ} \mathrm{C}$, followed by ion exchange chromatography was also described by Ninawa et al. (2008). A recovery yield of $58.92 \%$ was obtained at the precipitation step.

Even though the recovery results obtained here for the precipitation of both endoglucanase and xylanase with ammonium sulfate were lower than those found in the literature, it is worth mentioning that the precipitation conditions used in the experimental design for aging time and temperature $\left(3 \mathrm{~h}\right.$ and $10^{\circ} \mathrm{C}$ ) are more suitable for industrial applications, as compared to an overnight precipitation at $4^{\circ} \mathrm{C}$.

\section{Ethanol Precipitation}

The maximum efficiency of precipitation for endoglucanase and xylanase using ethanol as the precipitant agent was achieved at the same condition as using ammonium sulfate: concentration of $80 \%$ $(\mathrm{v} / \mathrm{v}), 10^{\circ} \mathrm{C}$, and an aging time of $180 \mathrm{~min}$, resulting in activity recoveries of $40 \%$ and $23 \%$, respectively. 
Ethanol concentration and aging time, as well as the term related to the interaction between temperature and aging time, showed statistical significance, within the confidence limit of $95 \%$, for both endoglucanase and xylanase activity recoveries (Table 5). Analyzing the effect of each independent variable on the response variables, the concentration of the precipitant ethanol was the one that had a greater effect on both enzyme recoveries, followed by the aging time. While the effects of ethanol concentration and aging time were positive, the interaction effects between temperature and aging time showed a negative effect. Thus, the increase in both ethanol concentration and aging time favored the precipitation of both enzymes at the lower temperatures level $\left(10^{\circ} \mathrm{C}\right)$, whereas at temperature level $+1\left(30^{\circ} \mathrm{C}\right)$, higher enzyme activity recovery was achieved by increasing the ethanol concentration and reducing the aging time. This negative effect of the interaction between temperature and aging time is most probably related to protein denaturation. The higher the temperature, the greater are the chances of unfolding and, consequently, denaturing enzymes (Cortez and Pessoa Jr, 1999). A similar result was observed by Avelino et al. (1999) studying the recovery of cellulase by HPMC-salt precipitation using experimental design. A decrease in activity recovery at high temperatures for long aging times was observed, while high temperature and short aging times leaded to higher enzyme recovery.

The ANOVA analysis for both endoglucanase and xylanase activity recoveries (Table 6) showed that the coefficient of correlation $(0.8985$ and 0.9057 , respectively) and the $F$ test (4.75 and 5.15 times higher than the tabulated F-value at the $95 \%$ level of confidence, respectively), obtained when the analysis was carried out after exclusion of the terms that were not statistically significant, were satisfactory for the prediction of the models of Equations (4) and (5):
Endoglucanase Activity Recovery $(\%)=$

$$
19.25+8.75 \mathrm{X}_{1}+2.50 \mathrm{X}_{3}-4.50 \mathrm{X}_{2} \mathrm{X}_{3}
$$

Xylanase Activity Recovery $(\%)=$

$$
11.50+5.75 \mathrm{X}_{1}+2.00 \mathrm{X}_{3}-3.00 \mathrm{X}_{2} \mathrm{X}_{3}
$$

where $\mathrm{X}_{1}, \mathrm{X}_{2}$ and $\mathrm{X}_{3}$ are the coded variable concentrations of precipitant agent (ethanol), temperature and aging time, respectively. The curvature and the lack of fit were not statistically significant for both responses, i.e., in the region investigated, the data could be fitted well by the linear models. Therefore, the models of Equations (4) and (5) were suitable to describe the response surface plots for precipitation using ethanol (Figures 3 and 4).

Endoglucanase activity recovery obtained here $(40 \%)$ was higher than that described by Saha (2004), who studied the production, purification and characterization of an endoglucanase produced by the fungus Mucor circinelloides. From the fermentation medium containing a complex of enzymes, the endoglucanase was purified using a sequence of overnight precipitation with ethanol $(75 \% \quad \mathrm{v} / \mathrm{v})$ followed by two chromatographic steps. A recovery of $29 \%$ was achieved in the precipitation step.

In terms of xylanase activity recovery, the maximum result obtained for the experimental design $(23 \%)$ was inferior to the ones described by Cortez and Pessoa Jr. (1999). They studied the fractionation of $\beta$-xylosidase and xylanase through precipitation with ethanol at concentrations of 20 , 40,60 and $80 \%(\mathrm{v} / \mathrm{v})$ at different $\mathrm{pH}$ values. The highest $\beta$-xylosidase and total xylanase recovery yield were achieved with ethanol concentrations of 60 and $80 \%$, respectively ( $74 \%$ of $\beta$-xylosidase and $80 \%$ of total xylanase recovery) by using an aging time of $15 \mathrm{~min}$ at $4^{\circ} \mathrm{C}$.

\begin{tabular}{|c|c|c|c|c|c|c|c|c|}
\hline \multirow[b]{3}{*}{ Factor } & \multicolumn{8}{|c|}{ Ethanol } \\
\hline & \multicolumn{4}{|c|}{ Endoglucanase } & \multicolumn{4}{|c|}{ xylanase } \\
\hline & Effect & $\begin{array}{l}\text { Standard } \\
\text { Error }\end{array}$ & $\mathbf{t}(2)$ & $\mathbf{p}$ & Effect & $\begin{array}{l}\text { Standard } \\
\text { Error }\end{array}$ & $t(2)$ & $\mathbf{p}$ \\
\hline mean & $19.25^{*}$ & 0.54 & 35.64 & 0.00 & $11.50^{*}$ & 0.41 & 28.17 & 0.00 \\
\hline curvature & 2.83 & 2.07 & 1.37 & 0.30 & -5.67 & 1.56 & -3.62 & 0.07 \\
\hline $\begin{array}{l}\text { Final concentration } \\
\text { of precipitant (1) }\end{array}$ & $17.50 *$ & 1.08 & 16.20 & 0.00 & $11.50 *$ & 0.82 & 14.08 & 0.01 \\
\hline Temperature (2) & -1.50 & 1.08 & -1.39 & 0.30 & 2.00 & 0.82 & 2.45 & 0.13 \\
\hline Time(3) & $5.00 *$ & 1.08 & 4.63 & 0.04 & $4.00^{*}$ & 0.82 & 4.90 & 0.04 \\
\hline $1 \times 2$ & -2.50 & 1.08 & -2.31 & 0.15 & 1.50 & 0.82 & 1.84 & 0.21 \\
\hline $1 \times 3$ & 0.00 & 1.08 & 0.00 & 1.00 & 2.50 & 0.82 & 3.06 & 0.09 \\
\hline $2 \times 3$ & $-9.00 *$ & 1.08 & -8.33 & 0.01 & $-6.00 *$ & 0.82 & -7.35 & 0.02 \\
\hline
\end{tabular}

Table 5: Statistical analysis for endoglucanase and xylanase activity recovery using ethanol as precipitant agent.

*Significant at the 0.05 level. 
Table 6: Analysis of variance (ANOVA) for endoglucanase and xylanase activity recovery using ethanol as precipitant agent.

\begin{tabular}{|c|c|c|c|c|c|c|c|c|c|c|}
\hline \multirow[b]{3}{*}{ Factor } & \multicolumn{10}{|c|}{ Ethanol } \\
\hline & \multicolumn{5}{|c|}{ Endoglucanase } & \multicolumn{5}{|c|}{ xylanase } \\
\hline & SS & df & MS & $\mathbf{F}$ & $\mathbf{p}$ & SS & df & MS & $\mathbf{F}$ & $\mathbf{p}$ \\
\hline curvature & 4.38 & 1 & 4.38 & 1.88 & 0.30 & 17.52 & 1 & 17.52 & 13.14 & 0.07 \\
\hline $\begin{array}{l}\text { Final concentration } \\
\text { of precipitant (1) }\end{array}$ & $612.50 *$ & 1 & 612.50 & 262.50 & 0.00 & $264.50 *$ & 1 & 264.50 & 198.38 & 0.01 \\
\hline Temperature (2) & 4.50 & 1 & 4.50 & 1.93 & 0.30 & 8.00 & 1 & 8.00 & 6.00 & 0.13 \\
\hline Time(3) & $50.00^{*}$ & 1 & 50.00 & 21.43 & 0.04 & $32.00 *$ & 1 & 32.00 & 24.00 & 0.04 \\
\hline $1 \times 2$ & 12.50 & 1 & 12.50 & 5.36 & 0.15 & 4.50 & 1 & 4.50 & 3.38 & 0.21 \\
\hline $1 \times 3$ & 0.00 & 1 & 0.00 & 0.00 & 1.00 & 12.50 & 1 & 12.50 & 9.38 & 0.09 \\
\hline $2 \times 3$ & $162.00 *$ & 1 & 162.00 & 69.43 & 0.01 & $72.00 *$ & 1 & 72.00 & 54.00 & 0.02 \\
\hline Lack of Fit & 89.00 & 4 & 22.25 & 9.54 & 0.10 & 37.50 & 4 & 9.38 & 7.03 & 0.13 \\
\hline Pure Error & 4.67 & 2 & 2.33 & & & 2.67 & 2 & 1.33 & & \\
\hline Total SS & 922.55 & 10 & & & & 426.18 & 10 & & & \\
\hline F cal & 20.65 & & & & & 22.42 & & & & \\
\hline Ftab & 4.35 & & & & & 4.35 & & & & \\
\hline Fcal/Ftab & 4.75 & & & & & 5.15 & & & & \\
\hline $\mathrm{R}^{2}$ & 0.8985 & & & & & 0.9057 & & & & \\
\hline
\end{tabular}

*Significant at the 0.05 level.

1. Values described for lack of fit and below were obtained for ANOVA analysis after exclusion of non-significant factors. $\mathrm{SS}=$ sum of squares; $\mathrm{df}=$ degrees of freedom; $\mathrm{MS}=$ mean square; $\mathrm{R}^{2}=$ Coefficient of correlation .

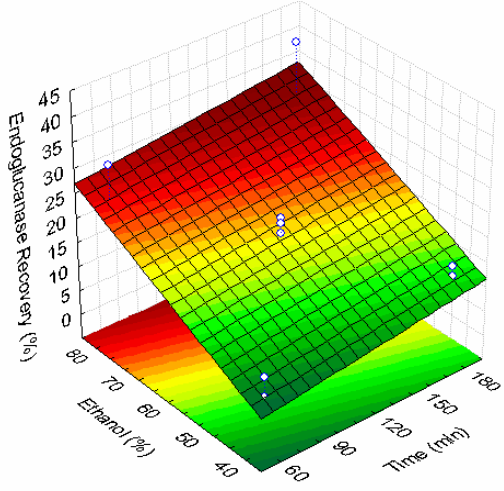

Figure 3: Response surface plot for the effect of aging time and concentration of precipitant agent on endoglucanase activity recovery after precipitation with ethanol.

\section{Precipitation Kinetics}

With the results from the precipitation of xylanase and endoglucanase obtained through statistical experimental design, it was possible to identify the effects of the variables aging time, temperature and concentration of the precipitating agent on enzyme recoveries. Higher recoveries for both endoglucanase and xylanase were achieved at the temperature of $10^{\circ} \mathrm{C}$ for $3 \mathrm{~h}$ and $80 \%$ concentration of the precipitant agent. Since the aging time showed a positive effect for all the conditions evaluated, we performed a study of the

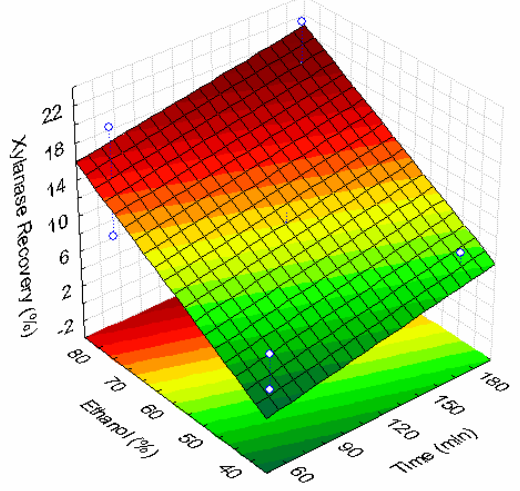

Figure 4: Response surface plot for the effect of aging time and concentration of precipitant agent on xylanase activity recovery after precipitation with ethanol.

precipitation kinetics for endoglucanase and xylanase in order to find the optimum aging time for the precipitation of these enzymes. The temperature selected for this study was $20^{\circ} \mathrm{C}$, given that this variable was not statistically significant for enzyme activity recovery and, in terms of energy consumption, a temperature closer to ambient temperature is more suited for large scale operation if the protein stability is not significantly affected. Under these conditions, the efficiency of precipitation of endoglucanase and xylanase was evaluated for different aging times ranging from 1 to $24 \mathrm{~h}$ (Figures 5 and 6). 


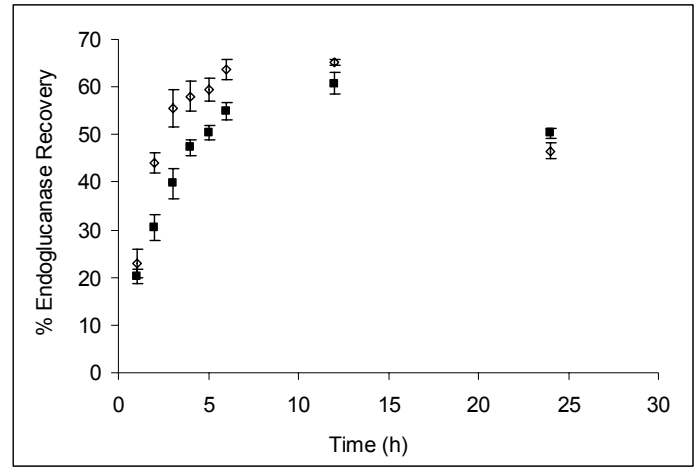

Figure 5: Kinetics of endoglucanase precipitation at $80 \%$ saturated ammonium sulfate $(\diamond)$ and $80 \%$ ethanol (v/v) (!) at $20^{\circ} \mathrm{C}$.

The precipitation of endoglucanase at $20^{\circ} \mathrm{C}$ and $80 \%$ concentration of the precipitant agent was slightly more efficient with ammonium sulfate than with ethanol. The yield of precipitation with ammonium sulfate reached an optimal value of $65 \%$ after $12 \mathrm{~h}$ of aging time. However, after $6 \mathrm{~h}$, the recovery was already very close to the equilibrium condition (64\%). Further increase in the aging time did not improve recovery, since after $24 \mathrm{~h}$ the efficiency of precipitation dropped to $46 \%$. The precipitation of endoglucanase with ethanol also had its optimum after $12 \mathrm{~h}$ of aging time, with an activity recovery of $61 \%$. We expect that the equilibrium condition for endoglucanase precipitation was not achieved in the corresponding runs of the experimental design, since increasing the aging time from 3 to $6 \mathrm{~h}$ increased enzyme activity recovery from 56 to $64 \%$ by using ammonium sulfate and from 40 to $55 \%$ using ethanol as precipitant agent.

The kinetic curves for precipitation of xylanase by ammonium sulfate and ethanol were very similar. The optimum precipitation of xylanase was after $3 \mathrm{~h}$ with ammonium sulfate (activity recovery of $27 \%$ ). For precipitation by ethanol, the optimum occurred after $6 \mathrm{~h}$ (activity recovery of $25 \%$ ). However, after $4 \mathrm{~h}$, the efficiency of precipitation was already very close to this value.

The differences in the recoveries of endoglucanase as compared to xylanase for both precipitant agents used here could be related to their stability, since these two enzymes have molecular masses in the same range. The size of the molecule is an important variable in the precipitation of proteins. Large molecules have a greater chance of aggregation due to the presence of charged surface areas to match with another protein. The reported molecular mass for the endoglucanase of $A$. niger is around $40 \mathrm{kDa}$ (Akiba et al., 1995), whereas the molecular mass of xylanase is around $24 \mathrm{kDa}$ (Sardar et al., 2000) and $36 \mathrm{kDa}$ (Coral et al., 2002).

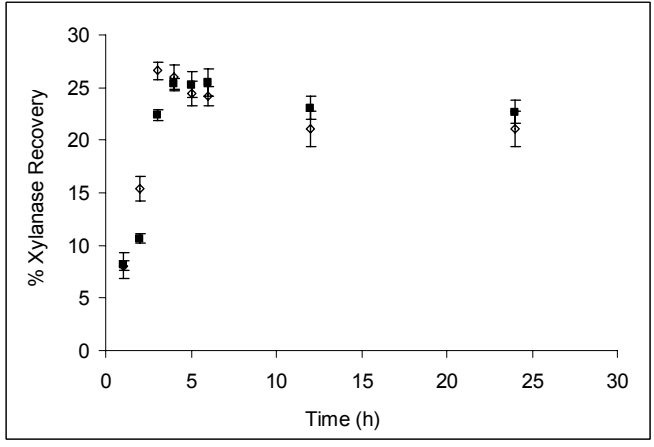

Figure 6: Kinetics of xylanase precipitation at $80 \%$ saturated ammonium sulfate $(\diamond)$ and $80 \%$ ethanol (v/v) (!) at $20^{\circ} \mathrm{C}$.

In terms of the precipitant agent used, both ammonium sulfate and ethanol resulted in similar values of activity recoveries. For industrial enzymes, a great advantage of ammonium sulfate for protein precipitation is the stabilization of proteins. The high salt concentration usually prevents proteolysis and bacterial action, making the protein precipitate stable for years (Scopes, 1994). A disadvantage would be the resulting concentration of salt in the process effluent streams, which needs to be at least partially removed in order not to compromise the environment. On the other hand, ethanol, besides being widely produced in Brazil can be recovered from the precipitate under reduced pressure due to its high volatility.

\section{CONCLUSIONS}

In this work, we evaluated the effects of operational parameters on the precipitation of endoglucanase and xylanase enzymes produced by solid state fermentation by using statistical experimental design. Precipitant agent concentration and aging time showed a positive effect on both endoglucanase and xylanase activity recoveries, while the temperature effect was not statistically significant within the range tested. In terms of the precipitant agent used, both ammonium sulfate and ethanol resulted in similar values of activity recoveries. The recovery of endoglucanase activity with ammonium sulfate and ethanol reached values up to 65 and $61 \%$, respectively. For xylanase, the recoveries rates were lower, reaching 27 and $25 \%$ with ammonium sulfate and ethanol, respectively. The results obtained by using the experimental design methodology allowed the selection of the variables relevant to improve enzymes activity recovery within operational conditions suitable for industrial applications. 


\section{ACKNOWLEDGMENTS}

The authors would like to thank Embrapa (Brazil) and $\mathrm{CNPq}$ (Brazil) for financial support.

\section{REFERENCES}

Akiba, S., Kimura,Y., Yamamoto,K. and Kumagai, H., Purification and Characterization of a Protease-Resistant from Aspergillus niger. Journal of fermentation and bioengineering, 79, No. 2, 125 (1995).

Avelino, S., Azzoni, A.R., Rosa, P. T. V., Miranda, E. A. and Santana, C. C., Recovery of cellulase by HPMC-Salt Precipitation. Applied Biochemistry and Biotechnology, 77-79, 807 (1999).

Bailey, M. J., Biely, P. and Poutanen, K., Interlaboratory testing of methods for assay of xylanase activity. Journal of Biotechnology, 23, 257 (1992).

Bokhari, S. A. I., Latif, A. F. and Rajoka, M. I., Purification and characterization of xylanases from Thermomyces lanuginosus and its mutant derivative possessing novel kinetic and thermodynamic properties. World Journal of Microbiology and Biotechnology, 25, 493 (2009).

Chahal D. S., Solid-state fermentation with Trichoderma reesei for cellulose production. Applied and Environmental Microbiolology, 49, 205, (1985).

Coral, G., Arikan, B., Ünaldi, M. N. and Korkmaz Güvenmez, H., Some properties of thermostable xylanasefrom an Aspergillus niger strain. Annals of Microbiology, 52, 299 (2002).

Cortez, E. V. and Pessoa, Jr. A., Xylanase and bxylosidase separation by fractional precipitation, Process Biochemistry, 35, 277 (1999).

Couri, S. and Farias, A. X., Genetic manipulation of Aspergillus niger for increased synthesis of pectinolytic enzymes. Revista de Microbiologia, 26, 314 (1995).

Ghose T. K., Measurement of cellulase activities. Pure and Applied Chemistry, 59, 257 (1987).

Himmel, M. E., Ruth, M. F. and Wyman, C. E., Cellulase for commodity products from cellulosic biomass. Current Opinion in Biotechnology, 10, 358, (1999).

Jabbar, A., Rashid, M. H., Javed, M. R., Perveen, R. and Malana, M. A., Kinetics and thermodynamics of a novel endoglucanase (CMCase) from Gymnoascella citrina produced under solid-state condition. Journal of Industrial Microbiology and Biotechnology, 35, 515 (2008).
Knauf, M. and Moniruzzaman, M., Lignocellulosic biomass processing: A perspective. International Sugar Journal, 106, No. 1263, 147 (2004).

Kumar, A., Galaev, I. Y. and Mattiasson, B., Precipitation of Proteins: Nonspecific and Specific. In: Hutti-Kaul, R. and Mattiasson, B., editors. Isolation and Purification of Proteins. New York: Marcel Dekker (2003).

Li, Y. H., Yin, Q. Y., Ding, M., Zhao, F. K., Purification, characterization and molecular cloning of a novel endo-beta-1,4-glucanase AC-EG65 from the mollusc Ampullaria crossean. Comparative biochemistry and physiology b-biochemistry \& molecular biology, 153, 149 (2009).

Lynd, L. R., Wyman, C. E. and Gerngross, T. U., Biocommodity engineering. Biotechnology Progress, 15, 777 (1999).

Miller, G. L. Use of dinitrosalicilic acid reagent for determination of reducing sugar. Analytical Biochemistry, 31, 426 (1959).

Ninawe, S., Kappor, M. and Kuhad, R. C., Purification and characterization of extracellular xylanase from Streptomyces cyaneus SN32. Bioresource Technology, 99, 1252 (2008).

Ogier, J. C., Ballerini, D., Leygue, J. -P., Rigal, L. and Pourquié, J., Production d'éthanol à partir de biomasse lignocellulosique. Oil Gas Science and Technology, 54, No 1, 67 (1999).

Oikawa, T., Kamatani, T., Kaimura, T., Ameyama, M. and Soda, K., Endo-b-Glucanase from Acetobacter xylinum: Purification and Characterization, Current Microbiology, 34, 309 (1997).

Saha, B. C., Production, purification and properties of endoglucanase from a newly isolated strain of Mucor circinelloides. Process Biochemistry, 39, 1871 (2004).

Sardar, M., Roy, I. and Gupta, M. N., Simultaneous purification and immobilization of Aspergillus niger xylanase on the reversibly soluble polymer EudragitTM L-100. Enzyme and Microbial Technology, 27, 672 (2000).

Scopes, R. K., Protein purification: principles and practice. New York: Springer, (1994).

Wilson, D. B., Aerobic Microbial Cellulase Systems. In: Biomass Recalcitrance - Deconstructing the Plant Cell Wall for Bioenergy, Blackwell Publishing (2008).

Wyman, C. E., Biomass ethanol: technical progress, opportunities, and commercial challenges. Annual Review of Energy and the Environment, 24, 189 (1999).

Zhang, Y. -H. P., Himmel, M. E. and Mielenz, J. R., Outlook for cellulase improvement: Screening and selection strategies. Biotechnology Advances, 24, 452 (2006). 